\title{
GEOMORPHOLOGICAL AND ARCHAEOLOGICAL STUDY OF THE BROADER AREA OF THE MYCENAEAN DAM OF MEGALO REMA AND ANCIENT TIRYNS, SOUTHEASTERN ARGIVE PLAIN, PELOPONNESUS
}

\author{
Maroukian H. ${ }^{1}$, Gaki-Papanastassiou K. ${ }^{1}$ and Piteros $\mathrm{Ch} .{ }^{2}$ \\ ${ }^{1}$ Department of Geography-Climatology, School of Geology, University of Athens, 15784 , \\ Athens,maroukian@geol.uoa.gr,gaki@geol.uoa.gr \\ ${ }^{2}$ D' EPKA (Ephoria of Prehistoric and Classical Antiquities), 21100 Nafplio
}

\section{ABSTRACT}

Along the eastern margins of the Argive plain, in the torrent of Megalo Rema and at a distance of 4 kilometers east of ancient Tiryns, lies the "Mycenaean dam of ancient Tiryns" a unique technological work of $13^{\text {th }}$ century B.C. It is believed that it was constructed for the effective protection of the immediate environs of the Mycenaean acropolis of Tiryns from the great floods of Megalo Rema torrent which was flowing just south of the citadel in Mycenaean times. This technical feat is survived in very good condition, having an almost N-S direction, a length of 80-100 meters, a base of 10 meters and an extant height of 8 meters. Its external side is lined with Cyclopean walls. The stability of the dam is strengthened by the presence of flysch on its southern end.

The diversion of the channel of Megalo Rema was accomplished by the digging of a $1.4 \mathrm{Km}$ long artificial channel having a SSW direction and joining downstream with the natural channel of Agios Adrianos Rema which discharges in the Gulf of Argos farther south from ancient Tiryns. The course of this downstream part of the new Megalo Rema was again diverted by the Venetians around 1500 A.D.

The presence of this dam comprises a fundamental reference point for the geomorphological evolution of this area in the last 3200 years, given that when it was constructed the drainage network of Megalo Rema had already incised in the Pleistocene sediments to a depth of about 10 meters as testified by its inactive channel behind the dam. The ensuing downcutting in the artificial channel during the last 3200 years is 2 meters below the depth of the inactive channel. The incision processes in this time period were not continuous resulting in the formation of a 3-4 meter inner alluvial terrace probably in post - Roman times.

The construction of the Mycenaean dam for flood protective purposes seems to be valid, but the study of the evolution of the broader coastal environment of the Tiryns acropolis leads to an equally important hypothesis that the high sedimentation rates of Megalo Rema had been creating serious problems in the sediment filling of this Mycenaean port whose operation was vitally important for the broader area of the Mycenaean Argive plain.

\section{INTRODUCTION}

Greece is very fortunate in having rich archaeological evidence covering several thousand years as a result of the flourishment of different civilizations such as the Mycenaean, Classical, Hellenistic, Roman and Byzantine. The information provided by the above evidence is very useful in the understanding of the palaeogeographical evolution of many parts of Greece. The Argive plain is one of the best areas where archaeology and geomorphology can be combined in order to determine the recent environmental evolutionary history of this area. 


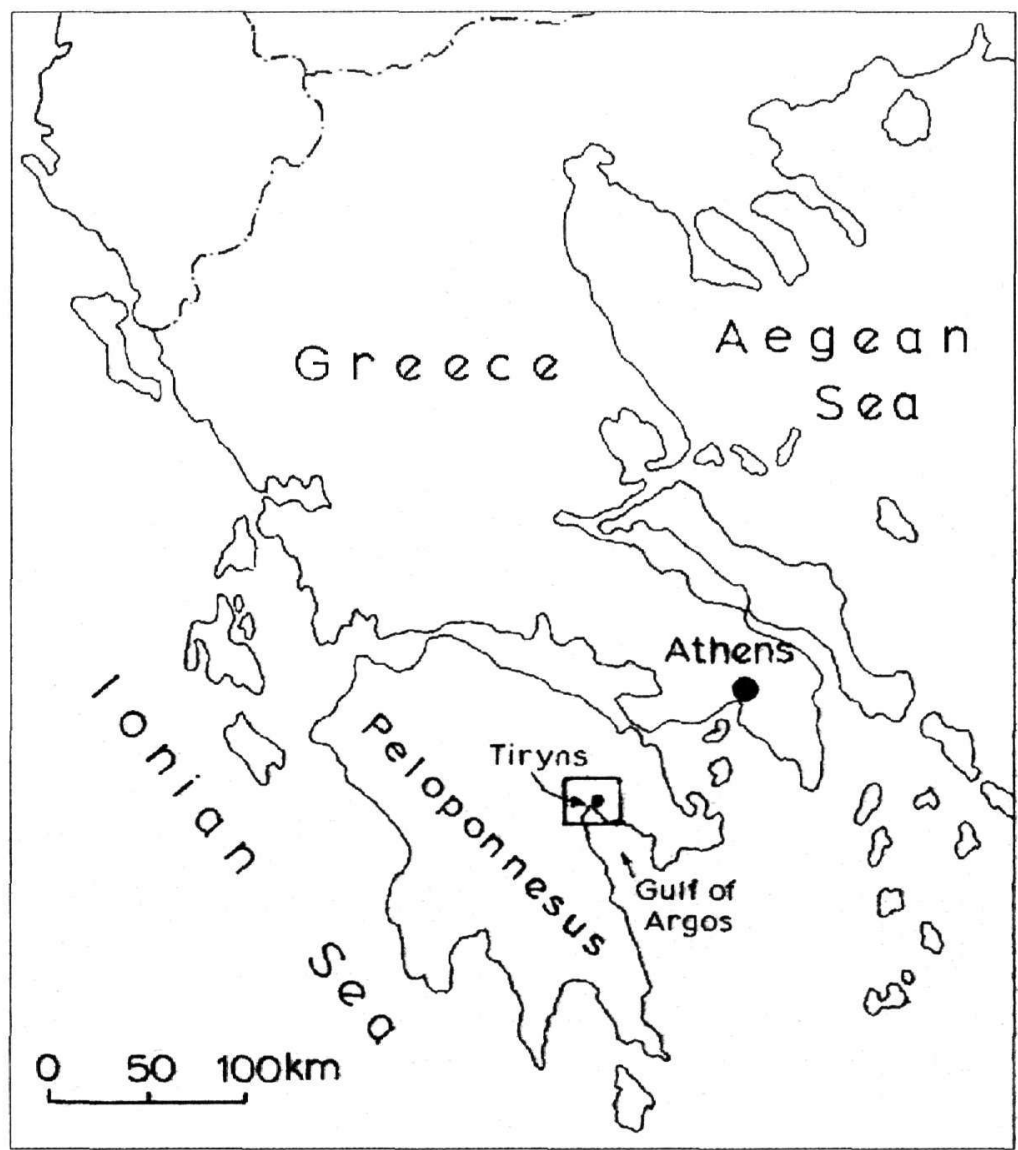

Fig. 1. Location of the study area in northeastern Peloponnesus.

The present study deals with a major constructional feat of the Mycenaean times, where great cities like Mycenae, Argos, Midea and Tiryns flourished in the second millennium B.C. (Fig. 1). It was a flood prevention dam near Tiryns in the southeastern Argive plain, which diverted a significant torrent to a nearby stream channel (Fig. 2, C). This archaeological work is a key element in the reconstruction of the palaeoenvironmental evolution of this area during the Late Holocene.

For this reason the present study aims to determine the morphological evolution of this area in the last 3000 years. In this context very detailed geomorphological mapping was performed in order to determine subtle changes that have taken place along the artificial channel dug out by the Mycenaeans.

\section{GEOLOGY}

The Argive plain is a tectonic depression of Plio - Pleistocene age. The eastern side of the plain where the study area is located is composed mainly of massive Triassic to Cretaceous limestones which tectonically are thrust over younger flysch formations (Fig. 3). On top of these, at lower elevations, there are Plio-Pleistocene lacustrine marls and fluvial conglomerates. In the coastal plain and in some valley bottoms there are Holocene alluvial and coastal deposits.

The general trend of the major faults of the Argive plain has a NW - SE direction which is responsible for the formation of the graben. The secondary faults which dominate the study area have $\mathrm{E}-\mathrm{W}$ and $\mathrm{NE}-\mathrm{SW}$ trends and control partially the flow directions of the torrents. 


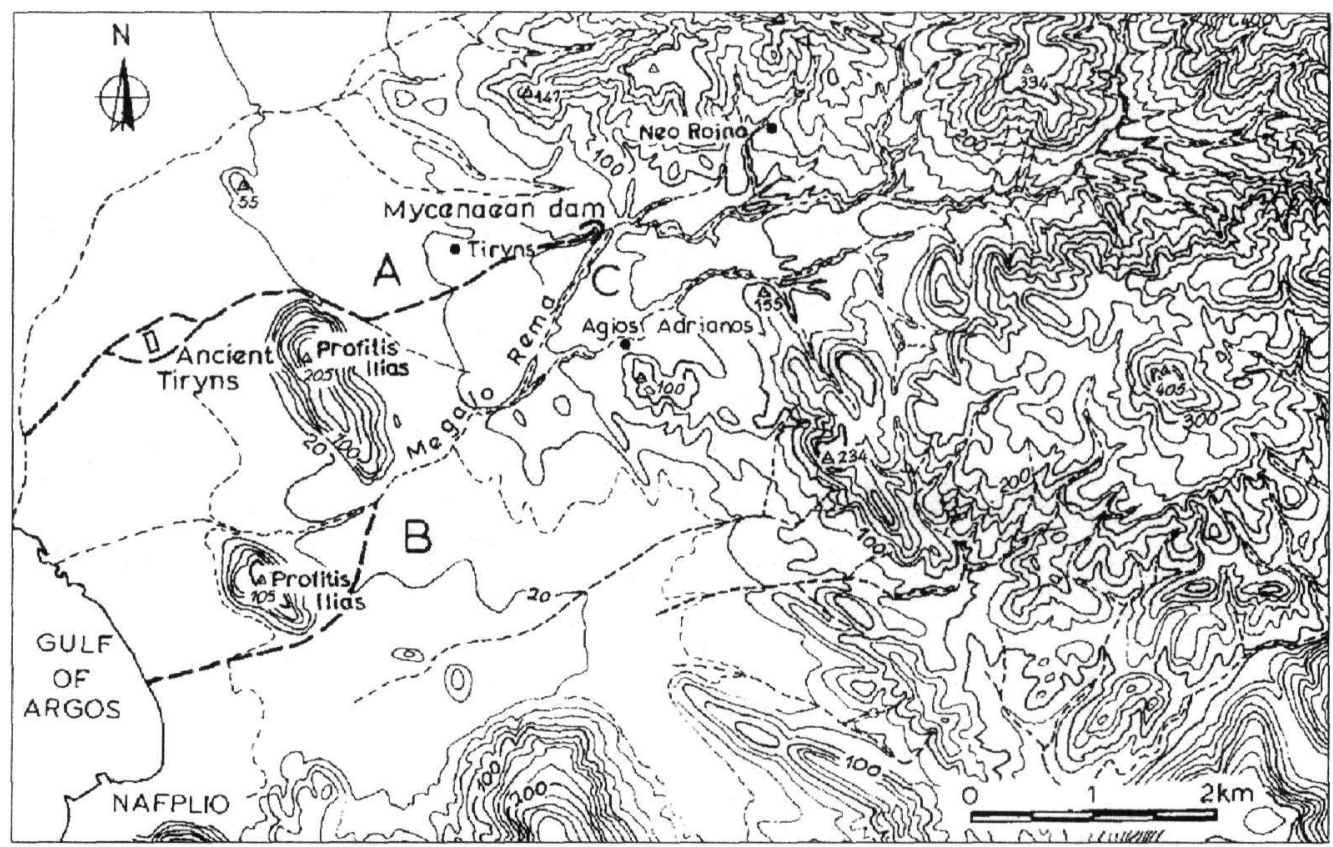

Fig. 2. Topographic map of the broader area of the Mycenaean dam of Megalo Rema and ancient Tiryns. A stands for the inactive channel 3200yrs ago, B for the most recent diverted channel undertaken by the Venetians around $500 \mathrm{yrs}$ ago and $\mathrm{C}$ stands for the artificial channel.

\section{THE MYCENAEAN DAM OF TIRYNS: THE ARCHAEOLOGICAL EVIDENCE}

At a distance of four kilometers to the east of the Mycenaean acropolis of Tiryns lies a dam, a distinct technical work of the Mycenaean period, in use until today, constructed for effective protection against floods which troubled the environs of the citadel and the ancient port of Tiryns (Fig.4)

The original (old) channel of Megalo Rema, has an E-W direction is still intact west of the dam. The dam has a length of $80-100$ meters with approximately N-S direction, a total height of 10 meters and a mean base width of about 60 meters.

The dam proper (the core) is constructed by natural red earth while on both eastern and western sides two protective walls have been built. The eastern protective wall is strong and large having an extant length of 80-100 meters, height 8 meters, width about 10 meters and is constructed with the Cyclopean method of Mycenaean external defenses made up of partly processed large limestone blocks, while the inner part of the dam is composed of rock and dirt fill (Photo 1). The upper section of this wall and especially its inner side has almost entirely collapsed due to erosion, particularly by torrential floods, but also by the removal of blocks for building purposes in more recent times. There are still some well - preserved parts in the lower portions of the outer side of the retaining wall.

The northern part of the outer protective wall has been intensely eroded by floods and is preserved at a width of 1,5-3 meters. The northernmost curved end of the outer wall used to reach the southern side of the provincial road joining Neo Roino with Nea Tiryns. Unfortunately, this section of the wall was destroyed in 1998 by illegal widening works of the road undertaken by the municipality of Nea Tiryns.

The western protective wall is smaller and much lower than the eastern one and is not discernible today. This wall was not affected by the hydraulic pressure of the torrent. It is noteworthy that both protective walls have a curved shape. The dirt and the core of the dam comprises a smaller part of the eastern side while on the western it forms a smoother shape. 


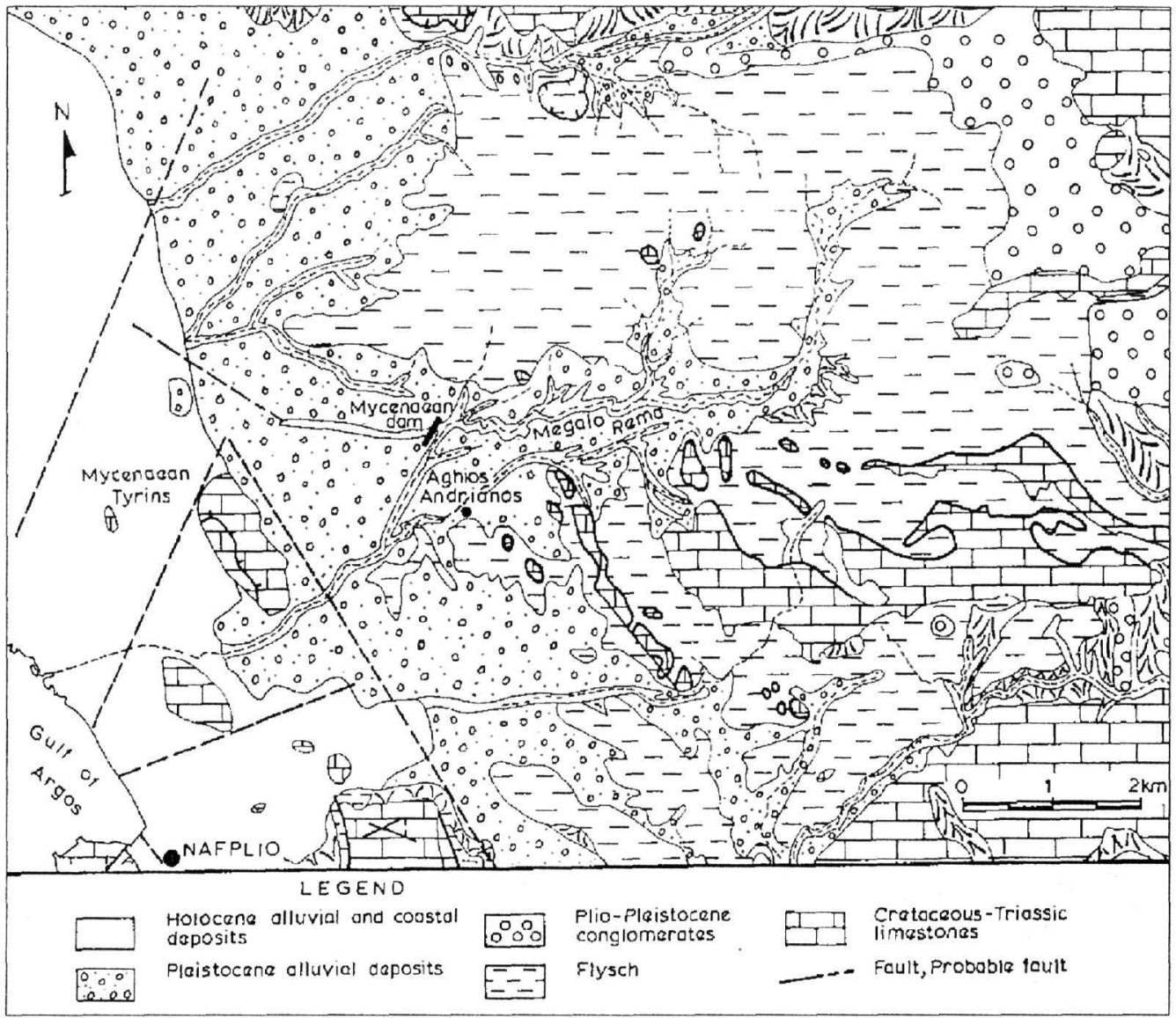

Fig. 3. Simplified geological map of the eastern side of the Argive plain.

Going to ancient Tiryns, Muller and Oelmann excavated geometric age graves in 1912 where they discovered that the Mycenaean foundation walls were 1.40 meters below the ground surface. The graves to the southeast of the citadel also lay within the course of a former stream bed and its alluvial deposits.

The first reference made for the Mycenaean dam was by $G$. Karo in 1930, who during excavations at Tiryns came upon fluvio - torrential deposits around the citadel (acropolis) and he correctly attributed them to Megalo Rema and the protective dam.

The ephor $\mathrm{N}$. Verdelis in 1963, engaged in archaeological excavations south of the citadel, encountered fluvial deposition down to a depth of 2.80 meters, which he dated to the Early Bronge age (Early Helladic II, second half of the third millennium B.C.) up to historical times. Verdelis associated these deposits to Megalo Rema and the abrupt cessation of flood deposits to the construction of the dam.

E. Slenczka (1973) during his archaeological work around Tiryns discovered 0.60 meter thick flood deposits and dated them to the Early Helladic II, like Verdelis did (1963). He related them to the Tiryns dam and the old channel of Megalo Rema and also to a new diversion channel south of the acropolis.

J. M. Balcer (1974) studied in the field the Mycenaean dam of Tiryns and gave an overview of all the work done in the area.

The archaeological study around the citadel of Tiryns by K. Kilian (1978) ascertained the habitation of the northern side of Tiryns during the Late Helladic IIIC period (Late Mycenaean, $1200-1100$ B.C.) upon a fluvio - torrential deposit. This habitation presupposes the security of 
complete protection of Tiryns by catastrophic floods which could be ensured only by the construction of a dam farther upstream.

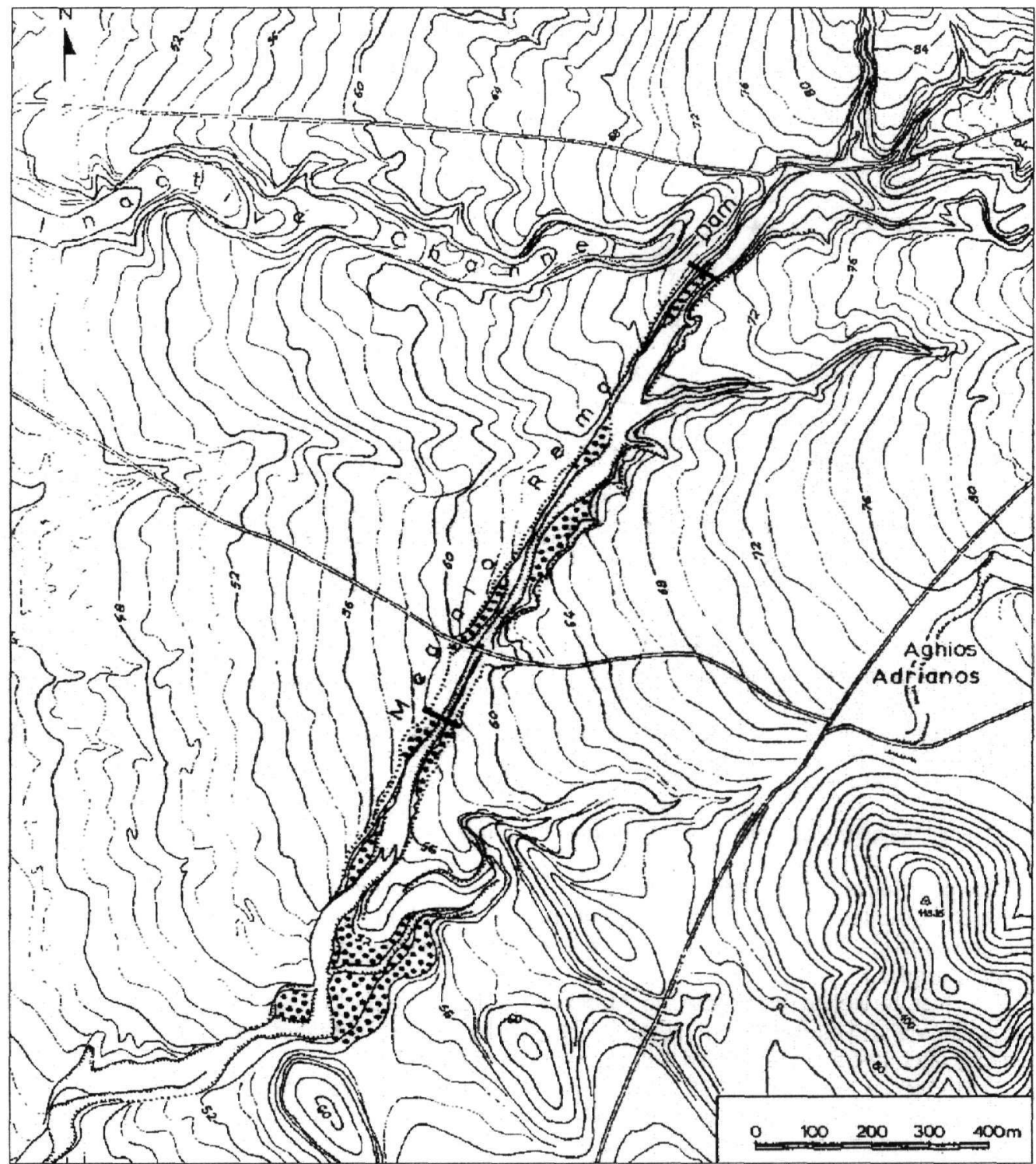

Fig. 4. Large scale morphological map of the Mycenaean dam of Megalo Rema showing the inactive channel and the artificial channel leading to the nearby torrent of Agios Adrianos. Note the inner alluvial terrace of postRoman times along the artificial channel and the position of the two nickpoints

The construction of such a large technical feat presupposes the existence of a strong central government. The dating of the construction of the dam during the Late Helladic III B period (1300 1200 B.C.) coincides with the most prosperous time of the Mycenaean civilization. According to the archaeological study as well as the geoarchaeological research of the Argolid by E. Zangger (1994) it was found that the old channel of Megalo Rema was flowing along the southern side of the acropolis of Tiryns until the Late Helladic III B period and it was then diverted to the north of the citadel obviously due to the catastrophic floods and heavy deposition of sediments. 
J. Knauss (1996), an engineer, dealt with the construction of the dam of Tiryns, the diversion of the main channel of Megalo Rema to the south and the technical dig up of the artificial channel for a total length of about 1,4 Kilometers.

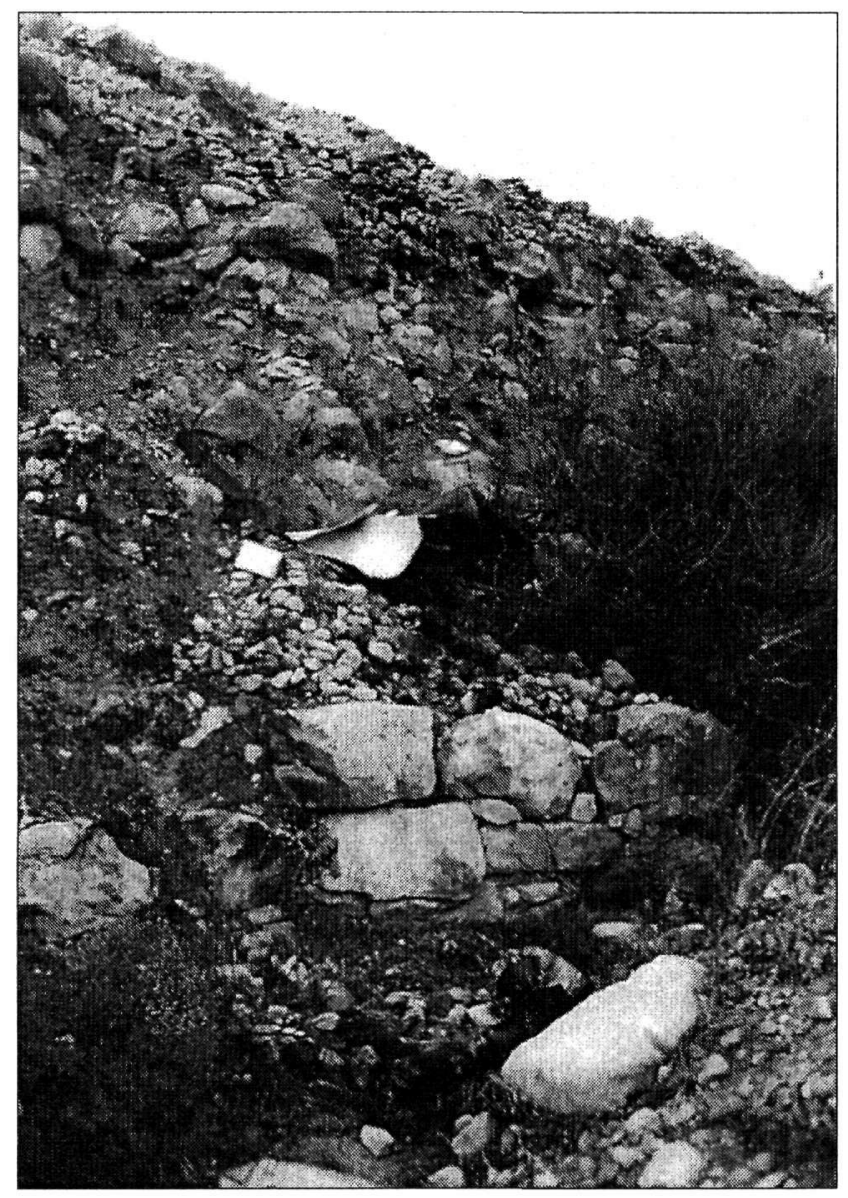

Photo 1. View of the Mycenaean dam with remnants of the eastern retaining Cyclopean walls on the side of the active channel. The core fill is made of dirt and large limestone blocks.

\section{GEOMORPHOLOGICAL OBSERVATIONS IN THE MEGALO REMA DRAINAGE SYSTEM}

The drainage network of Megalo Rema is developed mainly upon flysch formations with some limestone outcrops and is generally characterized by downcutting. The flysch is located in an E-W running tectonic depression between two limestone horsts. Most of the eastern part of the flysch was covered by fluvio-torrential deposits in the Plio - Pleistocene. The drainage network of Megalo Rema formed in the early Pleistocene and has partly eroded the Plio - Pleistocene formations while erosion has moved upstream into the flysch formations as well.

In the Middle - Late Pleistocene the network entered a depositional phase causing the accumulation of $15-20$ meter thick alluvial sediments.

Near the end of this depositional phase a brief erosional period is observed in the top 3-4 metres in the form of coarse - grained channel - fills. A period of intense downcutting followed, which at some points reached down to 10 meters and locally into the flysch formations. This period of incision continued into the Holocene. The presence of the Mycenaean dam located in the main 
channel of Megalo Rema indicates that the incised channel existed at that time. A depositional period in post - Roman times left a channel - fill type terrace of 3-4 meters.

In Late Holocene times the lower reaches of the Megalo Rema torrent changed positions several times both naturally and artificially. Until $3300-3200$ BP the mouth of Megalo Rema was located near Mycenaean Tiryns (Fig. 2). It seems that the river mouth was first located on the southern side of the citadel in the Early Helladic period and was then shifted on the northern side (Late Helladic period) or was on both sides of Ancient Tiryns (Zangger, 1994). This is evident in the morphology of the area deduced by detailed field investigation with the use of very large scale topographic sheets (1:2000). The mouth of Megalo Rema was very close to the hillock of Tiryns as the old coastline was right in front of it in the west (Kraft, 1974, Finke 1986, Gaki-Papanastassiou 1991). Sea level was 1.75 meters below present level $4500 y$ rs B.P. and 1.5 meters below sea level $3250 y$ rs B.P. and was about 200 meters west of the citadel of Tiryns (Knauss 1996). Today the present coastline lies about 2 Kilometrs SW from the acropolis of Tiryns.

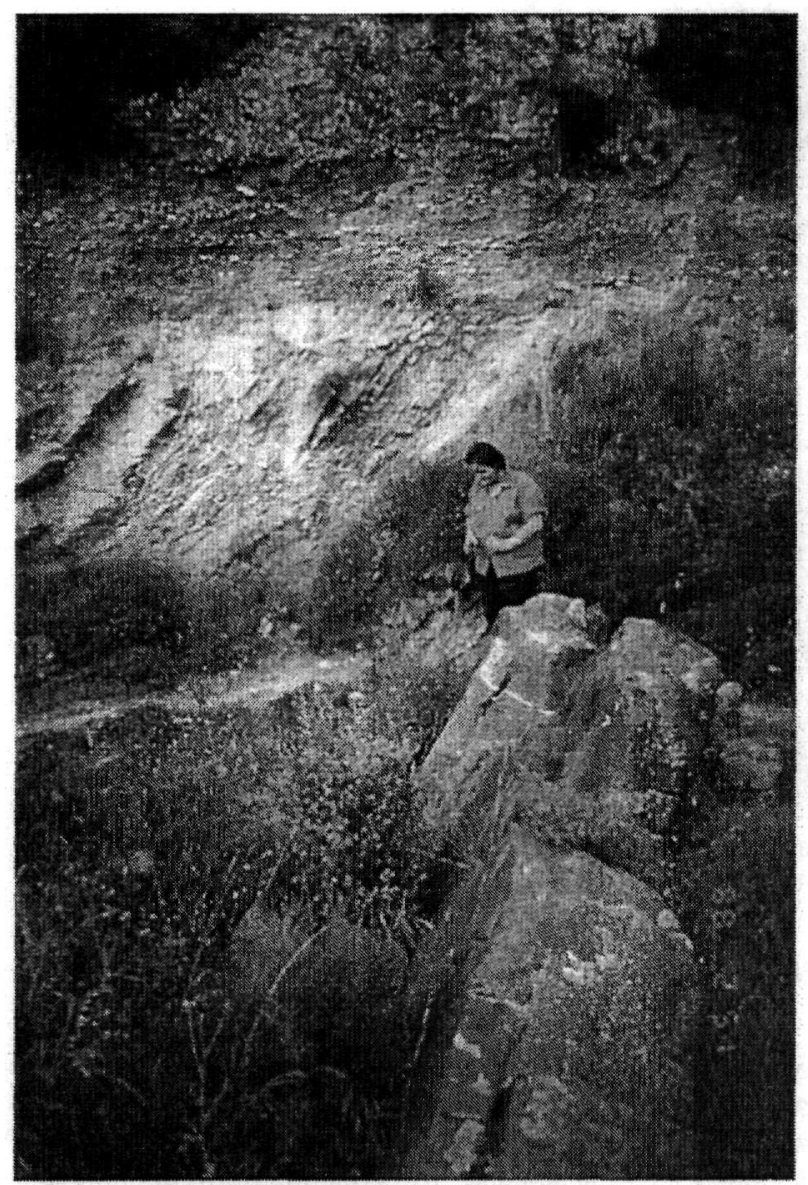

Photo 2. View of the lithological knickpoints at the beginning of the artificial channel composed of flysch formations with the resistant sandstone strata being the most prominent. In the background the flysch strata are visible overlain by the Pleistocene fluvial-torrential deposits.

The construction of the Mycenaean dam farther upstream was accompanied by the diversion of the main channel of Megalo Rema to the south towards today's Agios Adrianos village thus directing it to flow south of Profitis Ilias knoll and then to the Gulf of Argos in the west. It is believed however that the main channel of Agios Adrianos torrent was even more to the south towards the modern city of Nafplion when the dam was constructed (Fig. 2, channel B). 
During the works undertaken in 1990-1991 to extend the irrigation channel of Anavalos (western Argive plain) at a short distance east of Profitis llias of Nafplio hill and immediately west of the provincial road from Nafplio to Agios Adrianos, the main channel of Megalo Rema was discovered having a width of 40-60 meters, a minimum depth of 3 meters and running NE-SW (Piteros, 1992). It thus becomes apparent that the original diversion channel ended up further south from Profitis Ilias hill and the gulf of Nafplio.

The present channel of Megalo Rema flowing between the two hills of Profitis llias was probably emplaced around 1500 A.D. by the Venetians for the more affective protection of Nafplio from floods. It is worth mentioning that at that time, 500 years ago, the Venetians shaped and fortified the city of Nafplio giving it its present shape.

The location for the construction of the dam is the most appropriate as it is situated just below the confluence of two tributaries with the main channel. There are no tributaries downstream of the dam in the inactive channel and thus no significant additional water flow towards ancient Tiryns. An additional reason for the construction site is that the flysch formation reaches very close to the top of the quaternary sediments and was used as a support on the southern end of the dam. The artificial diversion channel is straight with a length of approximately 1,4 Kilometers. Since the downcutting of the main channel of Megalo Rema had reached a depth of 10-12 meters, the artificial channel had to be deep enough to accommodate the discharge of flood stages through it. So we believe that the easiest way to dig out the channel would have been the construction of a step-like trench with five 1,5 meters high and 2 meters wide steps and a channel bed of 4 meters.

Thus, the artificial channel would have a width of 20 meters and a depth of 7,5 meters making it possible to facilitate flood discharge. The remaining depth down to at least 10 meters where the main channel was located would have been incised by river erosion after forming a small lake behind the dam. The formation of the temporary small lake would have served as a dampening obstacle to the high flood flow rates of the torrent.

As a consequence of the constructions of the dam, the section of the main channel of Megalo Rema farther downstream became inactive and has remained so until today. Since no changes have taken place along this channel for the last 3200 years the morphology observed today reflects a picture of how Megalo Rema's main channel was at the time of the construction of the dam and has changed only a little, filled with colluvial sediments from the sides of the channel.

In the ensuing centuries, following the construction of the dam, continuous incision reached the artificial channel down to approximately the same depth where the natural channel was, that is about 10 meters. An old channel that had been flowing parallel and south of today's inactive channel in Mycenaean times became a tributary in its upstream section of the artificial channel (Fig. 4 and $5 \mathrm{~A}$ ). Thus this section followed the morphological evolution of the artificial channel which is very obvious in the longitudinal profile of Figure $5 \mathrm{~A}$, while the downstream part has remained inactive since the construction of the dam.

Some time in Late Roman and Byzantine times a short period of aggradation occurred which is encountered in other parts of the Argive plain and the remaining Peloponnesus (Vita Finzi, 1969, Zamani et al., 1991). Following this depositional phase, a period of downcutting took place which continuous until today and has reached the level of the upstream natural channel. There are two locations along the artificial channel which are regarded as knickpoints; one at the beginning of the channel composed of flysch (Photo 2) and the other about a kilometer farther downstream where a 3-4 meter limestone knickpoint has been revealed. The first one is composed by intercalations of sandstones, marls and locally conglomerates which however behave differently when eroded. The most resistant is the sandstone and as the strata dip steeply against the flow of the torrent they become even more difficult to erode. 


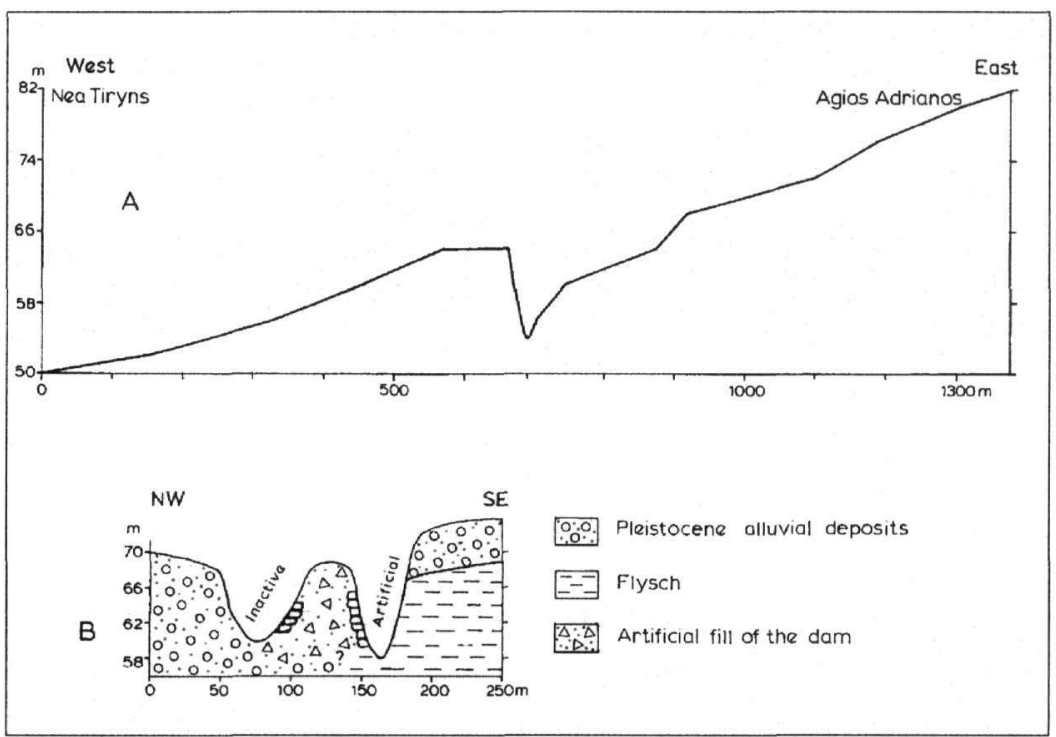

Fig. 5. A. Longitudinal profile of a tributary of the artificial channel of Megalo Rema. B. Cross section of the Mycenaean dam between the artificial and the inactive channels.

\section{CONCLUSIONS}

The geoarcheological study of an exceptionally well preserved manmade work has helped in the understanding of the environmental changes that have taken place in the late Holocene in this part of the Argive plain. The presence of the Mycenaean dam constructed 3200 years ago together with the excavation of an artificial channel led to significant conclusions regarding the geomorphological evolution of the study area.

The construction of the dam leads to the conclusion that incision of 10 meters had already taken place by that time. Since then about 2 meters of entrenchment has occurred. However this process was not continuous because in post Roman times a short period of aggradation took place in the artificial channel leading to 3-4 meter channel fill which was followed in the last centuries by downcutting and formation of a inner alluvial terrace.

Human interference in the natural evolution of Megalo Rema resulted at least in two diversions of the main channel. The first occurred in Mycenaean times and the second around 500 yrs ago. The coastline in Mycenaean times was about 200 meters southwest of the acropolis of Tiryns and close to 1.5 meters below present sea level.

Although it is generally accepted that the reason of the construction of the Mycenaean dam was for flood prevention, we believe that an equally important cause was for the mitigation of sediments in and around the port of Mycenaean Tiryns.

\section{REFERENCES}

Balcer J.M. 1974. The Mycenaean Dam at Tiryns. American Journal of Archeology, 78, 141-149.

Finke E. 1988. Landscape evolution of the Argive plain Greece, Palaeoecology, Holocene deposition and history and coastline changes. Ph. D. Thesis, Stanford University, 212p.

Gaki-Papanastassiou K. 1991. Geomorphological evolution of the broader Argive plain during the Quaternary. Ph. D. Thesis, University of Athens, Athens, 193p (In Greek with English abstract).

Gaki-Papanastassiou K. and H. Maroukian. 1995. Late Quaternary controls on river behaviour in the eastern part of the Argive plain, eastern Peloponnesus, Greece. Proceedings of the International Symposium on Mediterranean Quaternary River Environments, Cambridge, 1992, by Balkema, Rotterdam, 89-95.

Karo G. 1930. Archaeologische Funde. Archäologischer Anzeiger, $112 \mathrm{U}$.

Kilian K. 1978. Anggrabungen in Tiryns 1976. Archäologischer Anzeiger, 448-470 
Knauss J. 1996. Argolische Studien. Alte Strassen - Alten Wasserbauten, Flussumleituns von Tiryns. Munchen, 71-121.

Piteros Ch. 1992. Arhaeological observations in the broader area of Tiryns, Argolid. Archaeologiko Deltio, 94/B1.

Slenczka E. 1973. Damm und Kanal bei Kofini, in Fuhrer durch Tiryns, hrsg. V. U. Jantzen, Athens, 96p.

Verdelis N.M. 1963. Neue Geometrische Graber in Tiryns. Athenische Mitteilungen, 78, 1-62.

Vita Finzi C. 1969. The Mediterranean Valleys, Geological changes in historical times. Cambridge University Press, 140p.

Zamani A., Maroukian H. and K. Gaki-Papanastassiou. 1991. Rythmes de depot et de creusement pendant le temps historiques dans le cadre des sites archeologiques de la region d'Argos (Greece). Physio-Geo., $22 / 23,81-88$.

Zangger E. 1994. Landscape changes around Tiryns during the Bronze age, Am. J. Archaeol. 98/2, $189-212$.

ПEPI^H$\Psi \mathrm{H}$

\section{ГЕЛMOPФО^ОГIKH KAI APXAIO^OГIKH MEАETH TH $\Sigma$ EYPYTEPH $\Sigma$ ПEPIOXH $\Sigma$ TOY MYKHNAIKOY ФPAГMATO $\Sigma$

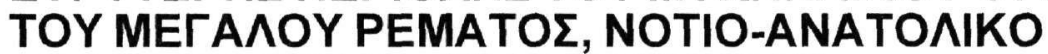

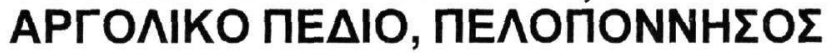

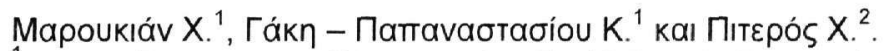

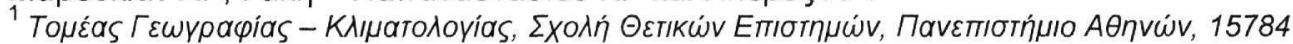
Aもńva, maroukian@geol.uoa.gr,gaki@geol.uoa.gr

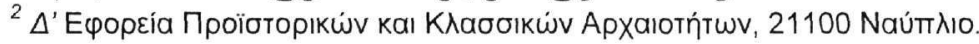

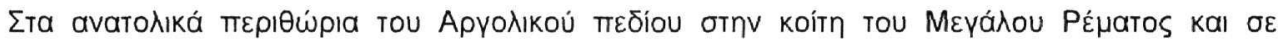

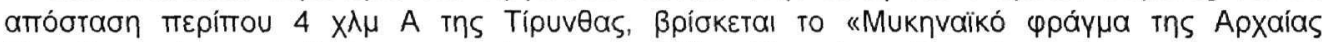

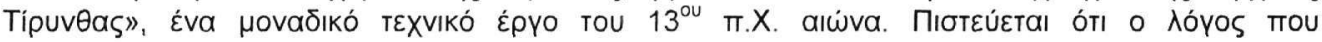

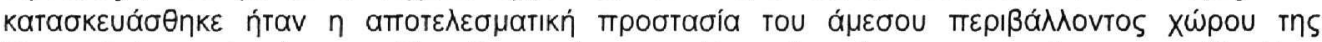

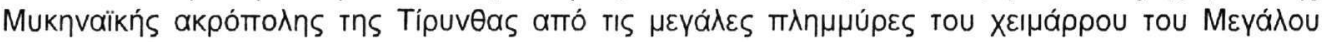

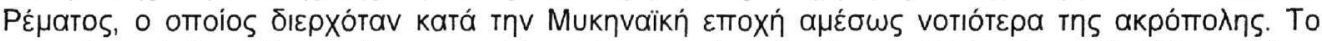

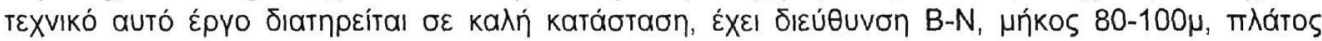

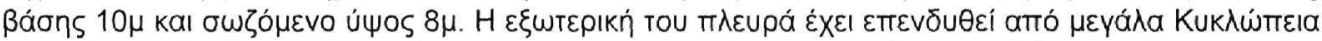

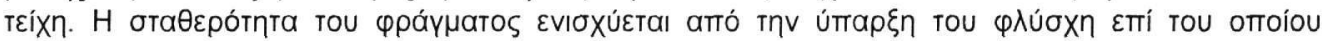

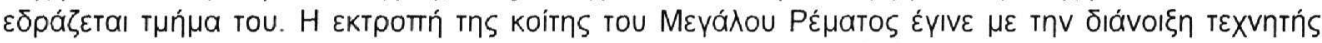

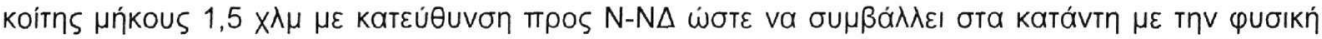

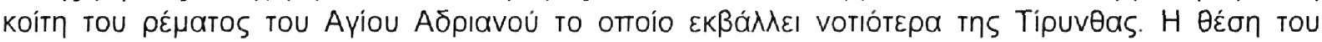

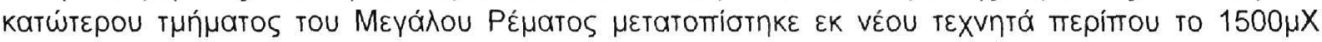
atтó tous Evetoús.

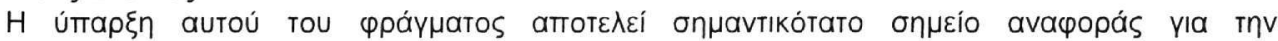

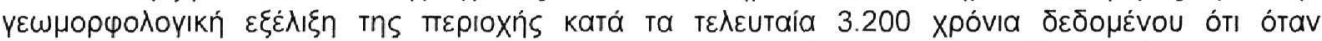

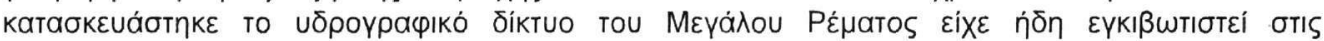

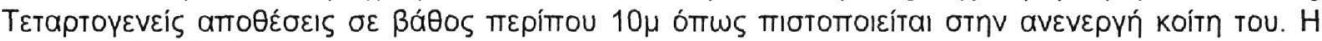

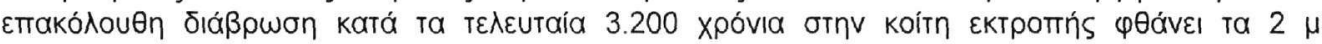

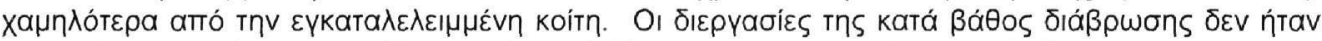

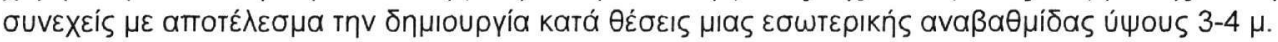

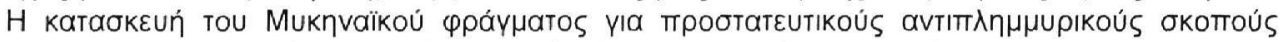

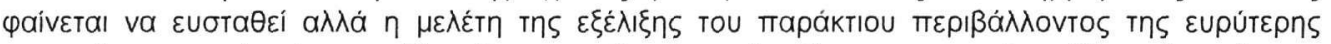

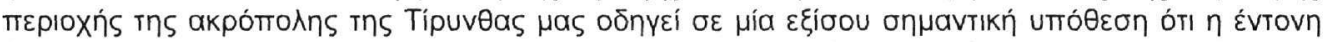

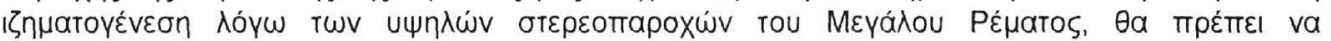

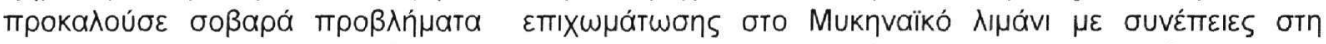

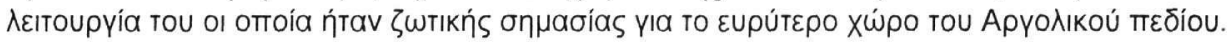

